\title{
PERAN MAQASID SYARIAH DALAM PEMBENTUKAN PERATURAN DAERAH (STUDI PENDEKATAN SISTEM JASSER AUDA)
}

\author{
Erfina Fuadatul Khilmi1 \\ Institut Agama Islam Negeri Jember \\ finakhilmi@gmail.com
}

\begin{abstract}
Abstrak
Paper ini bertujuan untuk memahami hukum islam, yakni maqasid syariah dalam memainkan peranan aktual atau kontemporer terhadap pembangunan hukum, khususnya mengenai pembentukan produk legislasi daerah, yakni Peraturan Daerah yang berkeadilan dan berkeadaban dalam rangka menuju keterbukaan dan pembaruan diri sebagaimana diharapkan hukum islam melalui mekanisme pendekatan sistem yang didasarkan pada pemikiran Jasser Auda. Metode yang digunakan adalah studi kepustakaan dengan analisis deskriptif analisis yang menguraikan secara lengkap, teratur dan teliti dalam mengelaborasi teori sistem Jasser Auda mengenai aktualisasi prinsip-prinsip maqasid syariah dalam pembentukan Peaturan daerah sebagai objek penelitian.. Berdasarkan hasil analisis, maka peran aktual maqasid syariah melalui pendekatan sistem dalam pembentukan Perda harus mampu menyeleksi dan mengakomodasi urf (kebiasaan) dengan mempertimbangkan nilai-nilai ajaran agama islam yang bersifat universal, sehingga efektifitas tujuan maqashid itu tercapai demi kemaslahatan masyrakat dalam mengokohkan keberagaman.
\end{abstract}

Kata kunci: Maqasid Syariah, Pembentukan Perda (Peraturan Daerah), Pendekatan Sistem Jasser Auda

\section{A. Permasalahan.}

Eksistensi Peraturan Daerah merupakan bagian yang tidak terpisahkan dari desentralisasi yang turut mempengaruhi daerah untuk mengatur dan mengurus daerahnya masing-masing melalui pembentukan Perda sebagai sarana menampung kondisi khusus daerah disamping melaksanakan tugas pembantuan dari peraturan perundang-undangan diatasnya. Ciri khas masing-masing daerah atau kondisi khusus daerah yang menjadi perhatian penting dalam pembentukan Perda seringkali menimbulkan euforia terhadap keunikan keberagamannya yang

1. Penulis adalah Dosen Tetap IAIN Jember dan saat ini tercatat sebagai mahasiswa Pascasarjana Program Doktoral S3 Universitas Islam Indonesia (UII) Angkatan 2018 Yogyakarta. 
lebih menonjolkan simbol-simbol keagamaan dan identitas lokal masyarakat di daerah. Hal tersebut mendorong daerah yang memiliki basis islam yang kuat untuk menerbitkan Perda bermuatan agama atau lebih dikenal dengan Perda Syariah.

Namun, konsekuensi dilaksanakannya Perda Syariah dibeberapa daerah seringkali juga menimbulkan perdebatan antara pendukung Perda Syariah dan kontra terhadap Perda syariah. Pendukung Perda Syariah menyatakan bahwa Perda Syariah akan membuat orang lebih merasa aman, tercermin nilai-nilai religius, menghormati dan melindungi kaum perempuan.2 Hal ini dikarenakan Perda Syariah telah menjadi bagian dari aspirasi masyarakat daerah yang menjadi identitas lokal dalam suatu daerah. Tetapi, kelompok yang kontra menganggap bahwa Perda Syariah menciptakan diskriminasi terhadap hak-hak perempuan dan membatasi kebebasan, sehingga mengancam keamanan perempuan.3 Selain itu juga, semestinya Perda harus berlaku umum dan isi materi muatannya tidak boleh menimbulkan sikap diskriminatif terhadap orang minoritas.Perdebatan-perdebatan formalisasi syariat islam dalam pembentukan Peraturan Daerah yang tidak pernah kunjung selesai, menimbulkan sebuah kegelisahan karena prinsip kemaslahatan, keadilan dan kesejahteraan tidak ditemukan dalam Perda Syariah tersebut dikarenakan interpretasi sebagian kalangan bahwa materi muatannya tidak ada yang bersinggungan dengan kondisi riil masyarakat sehingga kedudukannya dapat mengancam ideologi Pancasila, seperti Perda tentang kewajiban mngenakan jilbab di Bulukamba Sulawesi Selatan, Perda Pelarangan Pelacuran di Tangerang, Perda Minuman Keras di Jember, dan lainlain.

Berpangkal uraian diatas, maka tulisan ini akan berusaha menjawab pertanyaan mengenai bagaimana peran Maqasid Syariah dalam pembentukan Peraturan Daerah menurut pendekatan sistem Jasser Auda dalam menghadapi fenomena Perda Syariah di beberapa daerah di Indonesia. Tulisan ini dimaksudkan untuk memahami hukum islam, khususnya maqasid syariah dapat berkontribusi dalam pembangunan hukum khususnya Peraturan Daerah yang berkeadilan dan berkeadaban melalui pendekatan sistem berdasarkan pemikiran Jasser Auda yang diharapkan dapat memainkan peranan aktual atau kontemporer menuju keterbukaan dan pembaruan diri yang diharapkan hukum islam.

2. Erwin Nur Rif'ah, Contesting Perda Sharia And Women's Security In Indonesia, Jurnal al-A'dalah, Vol.16, No. 1,2013, hlm 4.

3. Ibid 


\section{B. Kerangka Teori}

\section{Teori Maqasid Syariah}

Terma Maqasid berasal dari bahasa arab maqasid yang merupakan bentuk jamak kata maqsad yang bermakna maksud, sasaran, prinsip, niat, tujuan, tujuan akhir.4 Sedangkan, syariah sebagai hukum-hukum Allah yang mengikat atau mengelilingi para mukallaf, baik perbuatanperbuatan, perkataan-perkataan, maupun i'tiqad-i'tiqadnya secara keseluruhan terkandung didalamnya.5 Dengan menggabungkan kedua kata diatas, Maqasid Syariah dari segi bahasa berarti maksud atau tujuan yang disyariatkan hukum Islam. Sehingga, yang menjadi bahasan utama di dalamnya adalah hikmat dan ilat ditetapkannya suatu hukum. Menurut Jasser Auda, Maqasid Syariah adalah prinsip-prinsip yang mencakup hikmah-hikmah dibalik hukum dan sekumpulan maksud ilahiah serta konsep-konsep moral yang menjadi dasar hukum islam, seperti keadilan, martabat manusia, kehendak bebas, kemurahan hati, kemudahan, dan kerjasama masyarakat6. Hal tersebut nantinya akan menjadi tujuan-tujuan baik yang ingin dicapai oleh hukum-hukum islam dengan membuka sarana menuju kebaikan atau menutup sarana menuju keburukan.

Jasser Auda mempresentasikan maqasid syariah dalam sistem (fitur) kebermaksudan (purposefulness) untuk mengukur efektivitas dan elemen hukum islam berdasarkan tingkat pencapaian maqasid, sebagaimana dikemukakan oleh Gharajedangi yang menilai suatu sistem sebagai sistem yang serba bermaksud (memiliki fitur kebermaksudan) jika: (1) sistem itu mencapai hasil (outcome) yang sama dengan cara-cara yang berbeda pada lingkungan yang sama dan (2) mencapai hasil yang berbeda-beda pada lingkungan yang sama atau pada lingkungan yang berbeda-beda pula.7 Dalam konteks tulisan ini, sistem kebermaksudan dapat menghasilkan produk hukum daerah yang responsif dan riil dalam penerapan asas desentralisasi di negara hukum Pancasila yang berdasarkan pada sistem hierarki peraturan perundang-undangan. Otonomi yang riil ini bisa dilakukan sepanjang produk-produk hukum tersebut mempresentasikan hak-hak dan kepentingan masyarakat lokal sebagaimana maksud yang

4. Mohammad al-Tahir dalam Jasser Auda, Maqashid Al-Shariah as Philosophy Of Islamic Law: A Systems Approach, London, The International Institute of Islamic Thought, 2007, hlm 32.

5. Abu Ishaq Al-Syatibi dalam http://etheses.uin-malang.ac.id/934/6/11210010\%20Bab\%202.pdf, diakses pada 13 Februari 2019.

6. Muhammad Faisol, Pendekatan Sistem Jasser Auda Terhadap Hukum Islam: Ke Arah Fiqh PostPostmodernisme, Kalam (Jurnal Studi Agama dan Pemikiran Islam), Vol. 6 No.1, Juni, 2012, hlm 43.

7. Mohammad al-Tahir dalam Jasser Auda, Maqashid Al-Shariah as Philosophy Of Islamic Law, Op...Cit..... hlm 32. 
hendak dicapai maqasid kontemporer, yakni kemaslahatan publik melalui pembangunan dan pengembangan SDM (sumber daya manusia) serta penguatan hak-hak asasi manusia.

\section{Teori Sistem Sebagai Pendekatan Terhadap Hukum Islam}

Istilah sistem berasal dari bahasa Yunani systema, yang berarti keseluruhan yang tersusun dari bagian-bagian atau komposisi8. Definisi umum sistem adalah serangkaian interaksi unit-unit atau elemen-elemen yang membentuk sebuah keseluruhan terintegrasi yang dirancang untuk melaksanakan beberapa fungsi.9 Definisi tersebut masih dianggap sederhana karena melihat sistem sebagai serangkaian unit-unit yang saling berinteraksi. Demikian juga, karakteristik khusus dari fitur sistem menurut Maturana dan Varela yang mengusulkan makhluk hidup untuk melestarikan atau memperbarui diri sendiri, sehingga menjadi sebuah sistem yang otonom namum indenpendensinya sebagian besar mengarah ke dalam dengan tujuan tunggal memelihara otonominya.10 Kasus dalam proses pembaruan dan reproduksi diri diadopsi oleh Luhmann yang menempatkan hukum sebagai sistem sosial agar hukum dapat merespons pada bagian lingkungannya yang diseleksi melalui norma-normanya dan mengubah dirinya melalui komunikasi yang terhubung secara internal,sehingga memelihara otonominya sendiri.11

Namun, ide pembaruan diri sebagaimana dikemukakan diatas tidak dapat diterapkan pada hukum islam, karena pembaruan (tajdid) muncul dari keterbukaan hukum dan interaksi hukum dengan lingkungan luar, bukan dari aktivitas internal yang diarahkan ke dalam.. Oleh karena itu, untuk memperbaiki keterbatasan-keterbatasan tersebut maka Jasser Auda menerapkan teori hukum islam dengan membangun seperangkat kategori12, yakni watak kognitif sistem (cognitive nature of systems), kemenyeluruhan (wholeness), keterbukaan (openness), hierarki yang saling mempengaruhi (interrelated hierarchy), multi-dimensionalitas (multidimensionality) dan kebermaksudan (purposefulness). Dari beberapa kategori tersebut, fitur kebermaksudan (purposefulness) dapat menjangkau fitur-fitur sistem hukum islam yang lain.

8. Lorens Bagus, Kamus Filsafat, Jakarta: PT. Gramedia, 1996,cet. I, hlm 1015.

9. Jasser Auda, Maqashid Al-Shariah....Op.Cit....., hlm 75.

10. Ibid, hlm 76 .

11. Ibid.

12. Jasser Auda, Membumikan Hukum Islam Melalui Maqasid Syariah, Yogyakarta: PT. Mizan Pustaka, 2015, Cet.I, hlm 321 


\section{Teori Pembentukan Peraturan Daerah}

Menurut Burkhardt Krems,13 pembentukan peraturan perundang-undangan meliputi dua hal pokok, yaitu kegiatan pembentukan isi peraturan di satu pihak dan kegiatan yang menyangkut pemenuhan bentuk peraturan, metode pembentukan peraturan, dan proses serta prosedur pembentukan peraturan di lain pihak. Dua kegiatan tersebut harus memenuhi persyaratan-persyaratannya sendiri-sendiri, apabila peraturan perundang-undangan hendak berlaku sebagimana mestinya, baik secara yuridis, secara politis, maupun secara sosiologis. Oleh karena itu, menurut Krems, pembentukan peraturan perundang-undangan merupakan kegiatan interdisipliner/ atau multidisipliner. Dalam konteks tulisan ini, peraturan perundangundangan yang dimaksud adalah Peraturan Daerah sebagai sebagai produk "secondary legislation", sedangkan "primary legislation" adalah undang-undang. Hal ini karena Peraturan Daerah itu merupakan bentuk "delegated legislation" sebagai peraturan pelaksana undang-undang ( subordinate legislation).14 Meskipun demikian, terdapat karakteristik Perda yang tidak dimiliki oleh peraturan perundang-undangan lainnya, yakni Perda sebagai sarana penampung kondisi khusus di daerah, artinya fungsi Perda yang tidak hanya sebagai penjabaran lebih lanjut dari peraturan perundang-undangan nasional tetapi sebagai sarana hukum dalam memperhatikan ciri khas masing-masing daerah dan kepentingan atau aspirasi masyarakat lokal.

\section{Pendekatan}

Paper ini mengkaji mengenai kontribusi Maqasid Syariah dalam pembentukan Peraturan Daerah berdasarkan pemikiran Jasser Auda. Pendekatan yang digunakan adalah sebagai berikut:

1. Pendekatan maqasid, yakni memahami struktur maqasid dengan mendeskripsikannya melalui struktur yang multidimensi untuk melakukan reformasi dan modernisasi dalam hukum islam dengan merepresentasikan pandangan-pandangan dan klasifikasi-klasifikasi yang valid, dimana tingkatan keniscayaan, ruang lingkup aturan-aturan, ruang lingkup orang dan tingkatan universalitas, seluruhnya adalah dimensi-dimensi valid.15

2. Pendekatan sistem hukum islam, yakni pendekatan holistic dimana entitas apapun dipandang sebagai satu kesatuan sistem yang terdiri dari sejumlah subsistem. Ada sejumlah fitur sistem yang dapat mempengaruhi analisis sebuah sistem terhadap komponen-komponen

13. Burkhardt Krems, Grundfragen der Gesetzgebungslehre, dalam A. Hamid Attamimi, Peranan.., hlm 317.

14. Jimly Asshiddiqie, Perihal Undang-undang, cet 3, Rajawali Pers, Jakarta, hlm 72.

15. Jasser Auda, Membumikan hukum Islam... Op.Cit, hlm 40. 
subsistemnya dan juga menetapkan bagaimana subsistem-subsistem ini berinteraksi satu sama lain maupun berinteraksi dengan lingkungan luar.

\section{Metode}

Pengumpulan data yang digunakan dalam penulisan makalah ini diperoleh melalui studi pustaka atau studi literatur yang menjadikan bahan pustaka sebagai sumber (data) utama yang bersifat teoritis. Makalah ini akan berusaha memaparkan bangunan pemikiran tentang peran Maqashid Syariah dalam pembentukan Peraturam Daerah melalui pendekatan teori sistem Jasser Auda, Data yang digunakan oleh peneliti adalah kajian pustaka dari buku-buku, jurnal ataupun literatur lain yang terkait dengan permasalahan penulisan makalah. Sedangkan dalam membahas dan menelaah data, penulis menggunakan metode deskriptif analisis yang menguraikan secara lengkap, teratur dan teliti dalam mengelaborasi teori sistem Jasser Auda mengenai aktualisasi prinsip-prinsip maqasid syariah dalam pembentukan Peaturan daerah sebagai objek penelitian.

\section{E. Konsep Dasar}

\section{Konsep Maqasid Kontemporer}

Konsep ini memberikan perhatian khusus pada perluasan dan reinterpretasi ide-ide yang mengutamakan pada kemaslahatan dan maqasid serta menilainya sebagai komponen-komponen dan reformasi fundamental dalam hukum islam dengan menyatakan bahwa hukum itu berubah seiring dengan perubahan waktu dan tempat atau mempertimbangkan faktor waktu dan tempat dalam ijtihad modern.16 Pergeseran paradigma teori maqasid lama yang berorientasi pada protection (perlindungan) dan preservation (penjagaan, pelestarian) menuju teori maqasid kontemporer yang lebih menekankan development (pembangunan, pengembangan) dan right (hak-hak) menunjukkan bahwa konsepsi-konsepsi kontemporer diyakini dapat memperbaiki kekurangan pada konsep maqasid klasik terutama ketika mengahadapi isu-isu masa kini dibandingkan konsepsi klasik, seperti Ibn Asyur yang memprioritaskan maqasid sosial di atas maqasid individual, Rasyid Rida memasukkan reformasi dan hak-hak asasi masyarakat ke dalam teori maqasidnya. Taha al-Alwani mengusulkan maqasid pengembangan peradaban di muka bumi dalam teorinya. Maqasid universal berbasis al-Qur'an yang digagas Yusuf alQaradawi bertujuan membangun keluarga dan bangsa yang baik.

Jasser Auda lebih menekankan konsep pembangunan sumberdaya manusia (human development) sebagai tema utama bagi kemaslahatan publik untuk merealisasikan hukum islam

16. Ibid, 233. 
yang lebih komprehensif karena realisasi maqasid dapat diukur secara empiris dengan mengambil manfaat dari Human Development Index (HDI) dan Human Development Targets yang nantinya dirujukkan kepada Maqasid Syariah yang lain17. Namun, ide-ide maqasid kontemporer sebagaimana yang telah diuraikan diatas, tidak dapat mendobrak kerangka berpikir yang berbasis sebab akibat dalam memainkan peranan aktual metodologi ijtihad hukum islam. Oleh karena itu, modernis islam memperkenalkan prinsip holisme melalui tafsir tematik.18

Dalam konteks tulisan ini, prinsip holisme menuntut penyatuan hukum dengan moralitas dan spiritualitas dalam satu pendekatan yang holistik. Hal ini berarti, pembentukan Peraturan

Daerah (Perda) yang berbasis maslahah (maqasid) dan selaras dengan hukum islam itu bersandarkan pada keseimbangan dan kenyamanan terhadap manusia sebagai subjek hukum yang sistemik dan integratif.

\section{Konsep Filsafat Sistem}

Filsafat sistem muncul pada paruh kedua abad ke-20 M sebagai anti-tesis terhadap filsafat modern dan postmodern. Filsafat modern yang menganggap bahwa seluruh pengalaman manusia bisa dianalisis dengan logika sebab-akibat dan menempatkan manusia sebagai pusat alam yang berdiri sendiri tanpa pemeliharaan tuhan, sedangkan filsafat post modern berupaya mendekonstruksi teori-teori mapan yang sudah dibangun oleh era modern yang selama ini baku, standart, dan tidak dapat diganggu gugart dipertanyakan kembali oleh post modernisme.

Kedua tesis dan pandangan tersebut ditolak oleh filsafat sistem dengan argumen bahwa alam semesta bukanlah sebuah mesin yang bergerak serba pasti (sebagaimana pandangan kalangan modernis), atau ciptaan yang tidak dapat diketahui sama sekali (sebagaimana pandangan postmodernis). Kompleksitas alam semesta tidak bisa dijelaskan hanya melalui sebab-akibat saja maupun irasionalitas non-logosentris. Problem dunia kontemporer tidak dapat hanya diselesaikan baik oleh perkembangan teknologi yang melesat maju maupun beberapa bentuk nihilisme.19 Oleh karena itu, filsafat sistem merupakan sebuah filsafat postmodernisme yang mengkritik modernisme dengan cara yang berbeda dengan teori postmodern yang berkiblat pada Eropa (non-logosentris). Tetapi, menurut filsafat sistem, pendekatan yang dapat digunakan untuk mengkritik modernisme maupun posmodernisme adalah melalui konsep-kosep

17. Ibid, 60 .

18. Jasser Auda, Maqashid Al-Shariah as Philosophy Op.Cit....., hlm 260

19. Ibid, hlm 64 . 
dari teori sistem, seperti keutuhan, multidimensi, keterbukaan dan berorientasi pada maqâshid, yang akan dimanfaatkan untuk memperbarui argumen-argumen teologis islam.

\section{Konsep Postmodernisme Dalam Hukum (Critical Legal Studies)}

Postmodernisme adalah kekuatan atau proses intelektual, politik dan kultural yang kontemporer, yang bertujuan mendekonstruksi dan memformat ulang banyak tradisi-tradisi artistik, kultural dan intelektual konvensional.20 Salah satunya adalah Studi Legal Kritis (CLS) yang merupakan suatu gerakan bahwa hukum tidak terpisahkan dari politik.. Mereka mengkritisi cara hakim dalam mempraktekkan hukum yang berorientasi pada asas-asas dan teori-teori hukum. Bagi aktivis dan filsuf CLS, pembentukan hukum yang dilakukan oleh hakim dalam memeriksa dan memutus kasus hukum sangat dipengaruhi oleh faktor non hukum,seperti pandangan hidup pribadi, situasi politik dan kepentingan sosial. Dengan demikian, mereka menolak hukum itu obyektif, otonom dan netral karena dalam penyelesaian kasus atau perkara itu cenderung mengeneralisasikan terma-terma yang termarginalkan seperti diskursus tentang kejahatan, gender, ras dan lain-lain.

Oleh sebab itu, Unger mengatakan, pembentukan hukum senantiasa mengandalkan interaksi dan negosiasi antar berbagai kelompok masyarakat, sehingga hukum tak terpisahkan dari politik dan berbagai norma non-hukum lainnya, seperti kepentingan ekonomi, ras, gender, atau politik21. Kalangan postmodern mendekonstruksinya melalui gerakan pluralisme hukum, sebab gerakan pluralisme hukum memungkinkan berbagai norma dan aturan yang secara "tradisional" tidak dikategorikan sebagai "hukum negara" ambil bagian dalam penyelesaian kasus. Bahkan berbagai norma dan aturan non-hukum tersebut turut mengubah norma hukum.22

\section{F. Sistematika}

Paper ini disusun atas 8 (delapan) bagian, yaitu sebagai berikut:

1. Kegelisahan akademik yang akan menguraikan fenomena dan perdebatan-perdebatan formalisasi syariat islam dalam pembentukan Peraturan Daerah yang tidak pernah kunjung selesai;

20 . V Taylor and C. Winquist, dalam Jasser Auda, Membumuikan hukum islam, Op.Cit, hlm 235.

21. Johan Setiawan dan Ajat Sudrajat, Pemikiran Postmodernisme dan Pandangannya Terhadap Ilmu Pengetahuan, Jurnal Filsafat, Vol.28 No, 1, Program Pascasarjana Universitas Negeri Yogyakarta, 2018, hlm 33.

22. Amin Abdullah dalam Johan Setiawan dan Ajat Sudrajat,....Op.Cit....,hlm 40. 
2. Kerangka teori, yang akan menjelaskan teori-teori yang relevan dengan permasalahan penelitian, yakni teori Maqasid Syariah, teori sistem dan teori pembentukan Peraturan Daerah;

3. Pendekatan, yakni alat analisis dalam menganalisa paper. Penulis menggunakan pendekatan maqasid, sistem hukum islam, multidisipliner;

4. Metode, yakni cara dan teknik penulisan paper. Dalam mengumpulkan data, penulis menggunakan studi pustaka atau studi literatur yang menjadikan bahan pustaka sebagai sumber (data)utama yang bersifat bersifat teoritis. Sedangkan, dalam menelaah data, pennulis menggunakan metode deskriptif analitis;

5. Konsep dasar yang menjadi dasar analisis penulis dalam menganalisa. Dasar analisa yang digunakan terkait paper ini, yakni konsep maqasid kontemporer, filsafat sistem, dan postmodernisme dalam hukum ( Critical legal Studies);

6. Sistematika, yakni susunan dalam tulisan paper ini;

7. Pembahasan, mengelaborasikan dan menjawab kegelisahan akademik dalam tulisan ini;

8. Simpulan, yakni hasil rekomendasi dari jawaban yang menjadi kegelisahan akademik dalam tulisan ini.

\section{G. Pembahasan}

Pendekatan sistem dalam tulisan ini merupakan pendekatan yang digunakan untuk memberikan suatu kontribusi dan peranan aktual Maqasid Syariah dalam menyelesaikan fenomena-fenomena terkait pembentukan Perda, khususnya polemik Perda bernuansa syariah di beberapa daerah yang tiada henti dijadikan perdebatan mengenai kemaslahatannya. Oleh karena itu, Jasser Auda mengusulkan konsep maqasid syariah melalui pendekatan sistem yang mempresentasikan masing-masing fitur dalam dua perspektif yakni teori sistem dan teologi islam. Hal tersebut diharapkan mampu membangun konklusi-konklusi filsafat sistem untuk memperbarui argumen-argumen teologi Islam, sehingga sebuah bukti terbaru tentang kesempurnaan Tuhan pada ciptaan-Nya lebih tepat dilandaskan pada pendekatan sistem, dibandingkan dengan argumen kausalitas terdahulu.23 Hal ini dikarenakan kerangka berpikir yang berorientasi pada kausalitas dengan memainkan peran logika dan supremasi sains telah gagal dalam mewujudkan nilai-nilai keadilan yang berimplikasi terhadap determinasi dan

23. Jasser Auda, Maqashid Syariah.... Op.Cit...., hlm 64. 
mengeneralisir persoalan. Oleh karena itu, pendekatan sistem yang disarankan Jasser Auda meliputi sebagai berikut:

\section{Watak kognitif sistem hukum islam}

Menurut teori sistem terdapat keterkaitan antara konsepsi dan realitas tanpa mengharuskan adanya identitas (konsepsi sama dengan realitas) maupun dualitas (konsepsi sama sekali tidak ada hubungannya dengan realitas)24. Dari korelasi tersebut, maka muncullah kerangka konseptual dari kognisi fakih yang berupaya untuk berijtihad dalam menyingkap makna yang tersembunyi dibalik nash dan impilikasi praktisnya. Namun, ijtihad yang demikian ini tidak boleh dianggap sebagai manifestasi literal dari perwujudan perintah tuhan tetapi merupakan pemahaman para fakih yang berusaha memahami nash melalui asumsi-asumsi. Meskipun implikasi dari pemahaman fakih itu berbeda-beda dalam menafsirkan nash, akan tetapi menurut Musawibah bahwa pendapat-pendapat hukum yang berbeda, berapa pun kadar kontradiksinya, semuanya adalah ungkapan-ungkapan yang sah (valid) dan seluruhnya benar (sawab)25.Hal inilah yang membuat hukum sebagai kebenaran yang paling mungkin berdasarkan asumsi-asumsi yang ada pada diri para fakih dan dikenal dengan fikih. konstruksi konseptual yang muncul dalam kognisi fakih ini tunduk pada penafsiran atau pandangan dunia seorang fakih. Artinya keputusan hukum yang dinilai oleh ahli fakih sebagai penilaian terhadap kebenaran yang paling mungkin atau dikenal dengan al-musawwibah. Hal ini lah yang membedakan dengan hukum atau pengetahuan Allah. Dalam hal ini, fikih digeser dari bidang pengetahuan ilahiah menuju bidang kognisi manusia terhadap pengetahuan ilahiah.

Namun, dalam konteks pembentukan Peraturan Daerah dari sudut pandang maqasid syariah, maka fikih secara praktis harus mampu mengakomodasi urf (kebiasaan) yang memenuhi persyaratan maqasid. Dapat dikatakan bahwa eksistensi maqasid disini adalah menyeleksi urf dengan mempertimbangkan nilai-nilai ajaran islam yang bersifat universal. Dengan demikian, fikih dan Urf harus sama-sama berkontribusi terhadap Peraturan Daerah. sehingga memberikan keleluasaan bagi pembentuk Perda untuk mengkonversi urf (kebiasaan) dan hukum-hukum fikih menjadi peraturan-peraturan yang otonom, riil dan sesuai dengan kebutuhan masyarakat. Namun, hal tersebut perlu ada penggalian dan pemaknaan kembali dalam mensinergikan urf dan hukum

24. Ibid, hlm 86.

25. Ibid, hlm 254. 
fikih, tidak sekedar apa yang tertuang atau menyalin (copy paste) ke dalam Peraturan Daerah itu sendiri. Artinya, harus ada prinsip-prinsip universalitas di dalamnya.

\section{Kemenyeluruhan Sistem Hukum Islam}

Pendekatan holistik atau menyeluruh merupakan suatu teori sistem yang menganalisis penjelasan fenomena secara keseluruhan, tidak hanya berpikir parsial sebab akibat tetapi relasi sebab-akibat itu berhubungan menghasilkan keterpaduan dalam sistem yang holistik. Hal tersebut tentunya akan berimplikasi pada pengembangan paradigma sebab-akibat menuju paradigma yang lebih holistik atau pendekatan penyatuan. Orientasi terhadap paradigma holistik tentu tidak mengenyampingkan hukum hukum tunggal dan parsial akan tetapi adanya sinergitas menyebabkan kaidah hukum yang parsial akan mendukung kaidah-kaidah holistik yang merupakan maqasid hukum yang harus diterapkan.

Prinsip holisme sebagaimana dikemukakan diatas dapat berperan dalam usulan pembaruan kontemporer Peraturan Daerah misalkan melalui pendekatan tafsir tematik. Pelaksanaan perda syariah tentang kewajiban mengenakan jilbab apabila dilihat dalam konteks peran maqashid, khususnya prinsip holisme maka pendekatan tafsir yang digunakan masih bersifat parsial. Hal ini dikarenakan tertuju pada golongan identitas mayoritas terbesar dalam suatu daerah sehingga standart ukuran moralitas yang paling sahih ditentukan oleh faktor-faktor spiritual dalam agama yang dominan disuatu daerah masyarakat. Oleh karena itu, diperlukan sejumlah metode pada berbagai tingkatan dan menuntut penyatuan hukum dengan moralitas dan spiritualitas dalam satu pendekatan yang holistik.26

\section{Keterbukaan Sistem Hukum Islam}

Sistem hukum islam adalah sistem yang terbuka yang memberikan fleksibilitas dalam menghadapi perubahan kondisi masa kini yang begitu cepat melalui mekanisme berinteraksi dengan lingkungan luar. Keterbukaan dan pembaruan diri yang diharapkan dalam hukum islam adalah sebagai berikut:

1. Memperbarui hukum dengan kultur kognitif

Dalam memperbarui hukum, perluasan ide uruf dari sudut pandang ide pandangan dunia (worldview) merupakan mekanisme usulan yang dapat digunakan oleh para fakih untuk menuju universalitas maksud hukum islam. Hal tersebut dikarenakan pandangan dunia dibentuk oleh segala sesuatu disekitar kita mulai dari agama, konsep diri, geografi dan lingkungan, hingga politik,

26. Al-Turabi, dalam Jasser Auda, Maqashid Syariah.... Op.Cit..., hlm 260. 
masyarakat, ekonomi dan bahasa.27 Dengan demikian, kultur kognitif mempresentasikan kultur dalam pengertian yang luas dan berkaitan dengan interaksi dunia luar sebagai realitas dalam rangka untuk mengakomodasi perubahan-perubahan dari adat kebiasaan baku bangsa Arab. Meskipun demikian, uruf yang dipresentasikan oleh seorang fakih adalah sesuai dengan pandangan dunianya yang sahih sepanjang tidak bertentangan dengan prinsip-prinsip dasar Maqasid Syariah. Hal tersebut dapat dimaknai bahwa setiap uruf itu seharusnya mengandung dimensi kemaslahatan yang tercermin melalui ajakan tauhid, etika, moralitas, konstruk sosial dan sebagainya. Demikian juga dalam pembentukan Perda, maka setidaknya diperlukan materi muatan uruf yang relevan dengan zaman sekarang sebagai substansi materi muatan Perda supaya secara positif memiliki daya guna pada masyarakat. Sehingga tidak asal itu menjadi ciri khas daerah tersebut tetapi juga membawa nilai-nilai universalnya,misalnya adat dikreasi untuk mengokohkan bangunan keberagaman atau pluralitas, toleransi beragama, penghormatan pada perempuan, penghargaan pada difabel dan sebagainya. dalam rangka mempercepat pembangunan dan kesejahteraan masyarakat Indonesia.28 Dengan demikian, menurut Jasser Auda, keseimbangan dalam memahami pandangan dunia dengan memasukkan fikih realitas akan mengurangi literalisme hukum islam dan konsistensi dalam area spiritual ibadah harus disinegikan dengan maqasid sosial lainnya yang juga bernilai ibadah.

2. Memperbarui Hukum melalui keterbukaan filosofis

Memelihara keterbukaan terhadap pengetahuan manusia melalui filsafat hukum Islam menjadi komponen yang penting dalam pengembangan hukum maupun pengetahuan islam,secara umum. Jasser Auda dalam hal ini banyak mengadopsi keterbukaan averroes (Ibn Rusyd) terhadap seluruh investigasi filosofis dan memperluas keterbukaan pada teori-teori usul fikih itu sendiri. Hal tersebut dikarenakan pemikiran Averroes (Ibn Rusyd) sangat terbuka dalam pengetahuan manusia. Keterbukaan itu diwujudkan melalui dalilnya mengenai manfaat penalaran filosofis yg berdasarkan akal sehat tanpa mempedulikan agama pembawanya. sehingga, apabila terjadi kontradiksi yang tampak antara penalaran sehat dan Nas adalah dengan melakukan reinterpretasi atas Nas,sejauh yang diperbolehkan bahasa,agar selaras dengan konklusi nalar.29

\footnotetext{
27. Ibid, hlm 263.

28. Noor Harisuddin, Wacana Adat Progresif, https://www.arrahmah.co.id/2019/01/26730/guru-besar-iain-jemberwacanakan-adat-progresif.html, diakses 23 Januari 2019.

29. Ibn Rusyd, dalam Jasser Auda, Maqasid Assyariah....Op.Cit, hlm 274.
} 


\section{Hierarki Saling Mempengaruhi Sistem Hukum Islam}

Sebuah sistem itu terbentuk dari sub-sub sistem yang menunjukkan hubungan interrelasi untuk mencapai tujuan yang dimaksud. Sub-sub sistem itu sendiri merupakan metode kategorisasi berbasis konsep-konsep yang integratif dan sitematis, sehingga sebuah analisis dalam hukum islam tidak akan berhenti pada hasil hierarki struktur pohon, melainkan juga diperluas untuk menganalisis hubungan saling mempengaruhi antara subkonsep-subkonsep yang telah dihasilkan30. Sehingga, dapat dikatakan sistem hukum islam sangat dipengaruhi oleh ideologi yang berkembang dari hasil pemikiran seorang fakih. Dalam hal ini, seorang fakih lebih mempertimbangkan sebuah konteks tertentu dalam menghadapi permasalahan sosial, misalnya konteks ekonomi, politik, budaya atau lingkungan). Pendekatan sistem Jasser Auda lebih pada konteks yang melingkupi alam pikiran seorang fakih yang dipengaruhi oleh kondisi luarnya. Demikian juga halnya dengan pembentukan materi muatan Peraturan Daerah yang mempresentasikan konteks suatu daerah yang dipengaruhi lingkungannya dengan tidak terjebak pada teks saja atau pendapat tertentu, sehingga maqasid syariah dapat diwujudkan.

\section{Multidimensi Sistem Hukum Islam}

Hukum islam adalah sebuah sistem yang memiliki berbagai dimensi, sehingga terhadap dilema dalil-dalil yang bertentangan atau berselisih maka tidak mesti dalil-dalil tersebut berada dalam keadaan yang tidak dapat dipecahkan. Yang terjadi dalam kasus ini adalah bukan pertentangan antar dalil tetapi cara berpikir yang kehilangan konteksnya dan tidak terkoneksi dengan hidup keseharian. Oleh karena itu, diperlukan metode konsiliasi dengan mengfungsikan konsep multi-dimensionalitas dalam memecahkan persolan diatas.. Pendekatan Maqasid sangat diperlukan dalam pembentukan Peraturan Daerah melalui pemahaman konteks yang mempertimbangkan uruf berdasarkan universalitas hukum islam yang akan menyajikan fleksibilitas dalam menghadapi perdebatan-perdebatan materi muatan Perda yang sempit ritual dan perlu dpertanyakan relevansinya di era kontemporer.

\section{Maqasid Sistem Hukum Islam}

Menurut Jasser Auda, Maqasid Syariah sebagai prinsip mendasar dan metodologi fundamental dalam analisis berbasis sistem.31 Metodologi analisis sistem yang menjangkau fitur-fitur sistem hukum islam yang lain adalah fitur kebermaksudan (Maqasid/ Purposefulness)

30. Ibid, hlm 91 .

31. Ibid, hlm 98 . 
yang tidak bersifat mekanik tetapi beragam dalam meraih tujuan akhir. Beragam disini dapat dipahami bahwa kebermaksudan itu memproduksi hasil yang berbeda di lingkungan yang sama sepanjang hasil-hasil yang berbeda itu meraih maksud-maksud yang diinginkan sesuai dengan situasi dan kondisi lingkungannya, sehingga tujuan penetapan hukum islam lebih berorientasi kepada kemaslahatan masyarakat disekitarnya. Kemaslahatan masyarakat merupakan tujuan akhir dari pembentukan peraturan daerah yang salah satunya dapat dicapai melalui mekanisme pandangan baru terhadap uruf berdasarkan maqasid hukum islam. Mempertimbangkan uruf merupakan langkah penting bagi hukum islam untuk menjadi hukum universal, hal ini dikarenakan Indonesia sebagai negara yang tidak berdasarkan agama dan akhirnya berimplikasi pada pemahaman agama sebagai nilai etis dalam kehidupan publik. Dengan berpijak pada nilainilai etika, maka diperlukan prinsip-prinsip maqasid yang diterima oleh semua umat manusia di bumi manapun sepanjang masa. Oleh karena itu, sebagaimana ditulis oleh Ibn Asyur yang menulis bahwa:32

" hukum islam tidak menyibukkan diri dengan menentukan apa jenis pakaian, rumah atau kendaraan orang seharusnya....Selaras dengan itu, kita dapat menetapkan bahwa kebudayaan dan adat istiadat masyarakat tertentu tidak boleh dibebankan kepada orang lain sebagai legislasi, bahkan tidak juga kepada individu dalam masyarakat yang memproduksi kebudayaan dan adat istiadat tersebut...

Berpangkal uraian diatas, berdasarkan maksud universalitas hukum islam, maka dalam pembentukan Perda diperlukan interpretasi untuk memaknai suatu aturan-aturan melalui pemahaman konteks kebudayaan yang melatarbelakanginya, sehingga aturan tersebut dapat dipahami dengan terwujudnya integrasi nilai-nilai moralitas dan spiritual dalam materi muatan Perda tersebut, bukan hanya sekedar memahaminya sebagai norna-norma semata. bagi Jasser Auda, metode yang berhubungan dengan uruf ini memperkaya fitur 'Maqasid' dalam hukum terakhir ini islam. 33

\section{H. K e s i m p u l a n}

Berdasarkan pembahasan di atas, maka dapat disimpulkan bahwa:

1. Peran dan kontribusi Maqasid Syariah dalam pembentukan Peraturan Daerah yang berkeadilan dan berkeadaban dapat dipahami melalui mekanisme pendekatan sistem Jasser Auda yang menjadi sarana untuk menata hubungan (korelasi) antara realitas yang dilandasi

32. Ibn Asyur, Maqasid al-Syari'ah al-islamiyah, dalam Jasser Auda,....Op.Cit...., hlm 313.

33. Ibid 
oleh prinsip kausalitas maupun non-kausalitas dengan membangun seprangkat kategori, yaitu watak kognitif sistem (cognitive nature of systems), kemenyuluruhan (wholeness), keterbukaan (openness), hierarki yang saling mempengaruhi ( interrelated hierarchy), multidimensionalitas (multidimensionality) dan kebermaksudan, dimana bagian terakhir ini adalah inti metodologi analisis sistem yang menjangkau kategori-kategori sistem hukum islam yang lain dan merupakan pengikat umum dikalangan seluruh fitur sistem lainnya.

2. Mempertimbangkan materi muatan uruf yang memiliki pandangan dunia (world view) berdasarkan kemaslahatan (maqasid/ purposefulness) dalam pembentukan Perda merupakan langkah positif untuk mengakomodasi uruf sebagai mekanisme yang memiliki daya guna pada masyarakat, mengurangi literalisme hukum islam dan akan menjadi ciri khas daerah tersebut untuk mengokohkan keberagaman.

\section{DAFTAR PUSTAKA}

Auda Jasser, Maqashid Al-Shariah as Philosophy Of Islamic Law: A Systems Approach, London:The International Institute of Islamic Thought, 2007, cet. III

Auda, Jasser, Membumikan Hukum Islam Melalui Maqasid Syariah, Yogyakarta: PT. Mizan Pustaka, 2015, Cet.I

Jimly, Asshiddiqie, Perihal Undang-undang, Jakarta: Rajawali Pers, 2012, cet.3

Bagus, Lorens, Kamus Filsafat, Jakarta: PT. Gramedia, 1996,cet. I

Faisol, Muhammad, Pendekatan Sistem Jasser Auda Terhadap Hukum Islam: Ke Arah Fiqh Post-Postmodernisme, Kalam (Jurnal Studi Agama dan Pemikiran Islam), Vol. 6 No.1, Juni, 2012.

Nur Rif'ah, Erwin, Contesting Perda Sharia And Women's Security In Indonesia, Jurnal alA'dalah, Vol.16,No. 1, 2013.

Setiawan, Johan dan Sudrajat Ajat, Pemikiran Postmodernisme dan Pandangannya Terhadap Ilmu Pengetahuan, Jurnal Filsafat, Vol.28 No, 1, Program Pascasarjana Universitas Negeri Yogyakarta, 2018.

Ishaq Abu Al-Syatibi dalam http://etheses.uin-malang.ac.id/934/6/11210010\%20Bab\%202.pdf, diakses pada 13 Februari 2019.

Harisuddin, Noor, Wacana Adat Progresif , https://www.arrahmah.co.id/2019/01/26730/gurubesar-iain-jember-wacanakan-adat-progresif.html, diakses 23 Januari 2019. 